\title{
Revisiting the work of Fred von Althen - an update on the growth and yield of a mixed hardwood plantation in Southern Ontario
}

\author{
by John H. Pedlar ${ }^{1}$, Saul Fraleigh ${ }^{1}$ and Daniel W. McKenney ${ }^{1,2}$
}

\begin{abstract}
Dr. Fred W. von Althen, formerly of the Canadian Forest Service, established hundreds of research plantations with a focus on identifying tree species and silvicultural techniques conducive to successful hardwood afforestation in southern Ontario, Canada. Here we provide an update, using 30-year remeasurement data, on the growth and yield of one of his most productive, and compositionally unique, mixed hardwood plantations. At age 30, the plantation exhibited the following characteristics on average: 1) density of $790 \mathrm{stems} / \mathrm{ha}$ — reduced from $2222 \mathrm{stems} / \mathrm{ha}$ at time of planting through natural mortality; 2) height of 14.4 meters; 3) quadratic mean diameter of $20.1 \mathrm{~cm}$; and 4) gross stand volume of $181 \mathrm{~m}^{3} / \mathrm{ha}$. With a mean annual increment (MAI) of $6.1 \mathrm{~m}^{3} / \mathrm{ha} /$ year, this plantation exhibits one of the highest published growth rates for mixed hardwoods in temperate North America. There was considerable variation in growth and yield between the 10 hardwood species making up the stand — silver maple, white ash, and black walnut had the highest growth rates, and red and white oak the lowest. Several Carolinian species, such as catalpa and sycamore, showed good growth rates, despite the study site being located north of their published range limits. This data set provides rare information on the growth and yield of mixed hardwood plantations in Canada.
\end{abstract}

Key words: growth and yield, southern Ontario, afforestation, mixed hardwoods, Carolinian species

\section{RÉSUMÉ}

Le Dr Fred W. von Althen, alors qu'il était à l'emploi du Service canadien des forêts, a mis en place des centaines de plantations à des fins de recherche dans le but d'identifier les espèces d'arbres et les techniques sylvicoles menant au reboisement réussi de feuillus dans le sud de l'Ontario au Canada. Cet article présente une mise à jour de ces travaux effectuée au moyen des données de remesurage étalés sur une période de 30 ans de la croissance et du rendement d'une des plantations les plus productives et des plus uniques du point de vue de la composition de feuillus mélangés. À l'âge de 30 ans, la plantation démontrait en moyenne les caractéristiques suivantes : 1) une densité de 790 tiges/ha, en baisse par rapport au 222 tiges /ha au moment de la plantation suite à la mortalité naturelle ;2) une hauteur de 14,4 mètres;3) un diamètre selon la moyenne quadratique de $20,1 \mathrm{~cm}$ et 4) un volume brut du peuplement de $181 \mathrm{~m}^{3} / \mathrm{ha}$. Avec une croissance annuelle moyenne (AAM) de $6,1 \mathrm{~m}^{3} / \mathrm{ha} / \mathrm{an}$, cette plantation démontre l'un des taux de croissance les plus élevés parmi ceux publiés pour des peuplements feuillus mélangés sous un climat tempéré en Amérique du Nord. Il existe une variation considérable dans la croissance et le rendement des espèces de feuillus composant le peuplement, l'érable argenté, le frêne d'Amérique et le noyer noir ayant les taux de croissance les plus importants, alors que le chêne rouge et le chêne blanc avaient les plus faibles. Certaines espèces originaires des Carolines, comme le catalpa et le sycomore, ont démontré de bons taux de croissance, malgré le fait que le site utilisé était situé au nord des limites reconnues dans la littérature de leur distribution. Cet ensemble de données constitue une information précieuse sur la croissance et le rendement des plantations de feuillus mélangés au Canada.

Mots-clés : croissance et rendement, sud de l'Ontario, reboisement, feuillus mélangés, espèces des Carolines

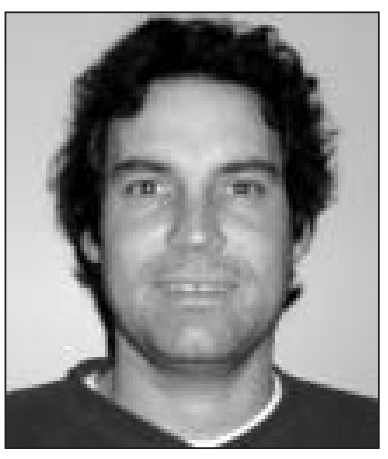

John H. Pedlan

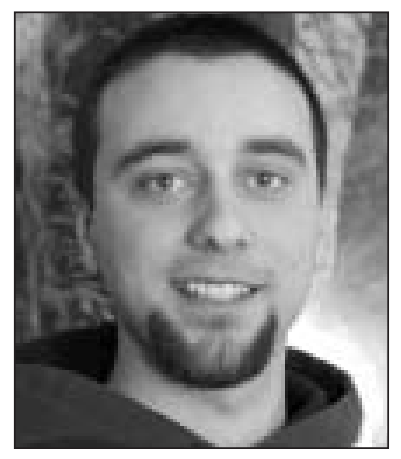

Saul Fraleigh

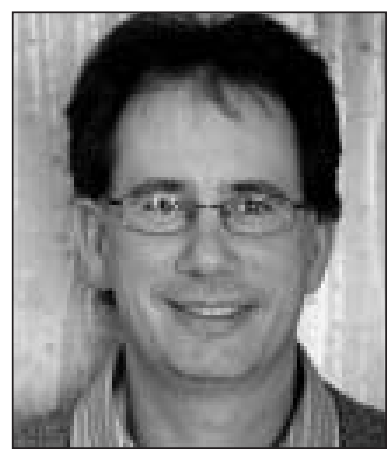

Daniel W. McKenney

\footnotetext{
${ }^{1}$ Natural Resources Canada, Canadian Forest Service, 1219 Queen St. E., Sault Ste. Marie, Ontario P6A 2 E5.

${ }^{2}$ Author to whom all correspondence should be addressed. E-mail: dmckenne@nrcan.gc.ca
} 


\section{Introduction}

Throughout the 1970s and 1980s, Fred von Althen of the Canadian Forest Service studied the use of hardwood species for afforestation activities in southern Ontario. His work left a legacy of research plantings throughout the region and provided detailed silvicultural prescriptions for the establishment of new hardwood plantations on fallow agricultural land (summary in von Althen 1990). Many of these stands remain relatively unchanged since the time of their establishment between 20 and 40 years ago. As part of the southern Ontario landscape, they provide valuable aesthetic and recreational opportunities, as well as helping to maintain ecosystem function in an area that is increasingly fragmented and burdened by human activities. Furthermore, these plantations offer the potential for ongoing research into the longterm effects of silvicultural treatments and the growth and yield of a unique variety of Ontario hardwood species.

Here we provide an update on the growth and yield of a particularly productive mixed hardwood plantation that was established by Fred von Althen in 1974 (von Althen 1988). We present this work for a number of specific reasons. First, there are remarkably few data on the growth of mixed hardwood plantations in southern Canada-despite evidence that they are often more productive than hardwood monocultures (von Althen 1988, Pedlar et al. 2006). Such data are needed to quantify the potential environmental and economic outcomes of multi-species plantings, which are increasingly used in afforestation efforts. For example, a recent afforestation initiative in Ontario, the Forest 2020 Plantation and Demonstration Assessment Program, established 1100 hectares of new forest-over $80 \%$ of which involved multispecies plantings (NRCan 2005). Furthermore, the species composition of this particular planting, with a combination of Carolinian and more northerly hardwoods represents a unique data set. This mixing of northern and southern tree species is made more interesting by growing evidence that climate change could bring about a major reorganization of North American tree species (Shafer et al. 2001, Iverson et al. 2005). We also hope that this short paper helps remind analysts and policy-makers of the value of ongoing monitoring of established forest research sites.

\section{Methods}

The study has been described previously (von Althen 1988), so only the main details are reported here.

\section{Study area}

The plantation is located on a former agricultural field near the town of Parkhill, Ontario (43.16525 N, $81.66934 \mathrm{~W}$ ). Mean annual temperature at the site is $7.68{ }^{\circ} \mathrm{C}$ and average annual precipitation is $941 \mathrm{~mm}$. Average growing season length is 225 days. Proper soil conditions are critical to hardwood plantation success (von Althen 1990); soil at the site consisted of a deep sandy loam.

\section{Stand establishment and management}

In the spring of 1974, seedlings of the following hardwood species were planted at a spacing of $3 \mathrm{~m}$ between rows and 1.5 $\mathrm{m}$ within rows: basswood (Tilia americana L.), black locust (Robinia pseudoacacia L.), black walnut (Juglans nigra_L.), catalpa (Catalpa speciosa Warder.), European mountain ash (Sorbus aucuparia L.), red oak (Quercus rubra L.), silver maple

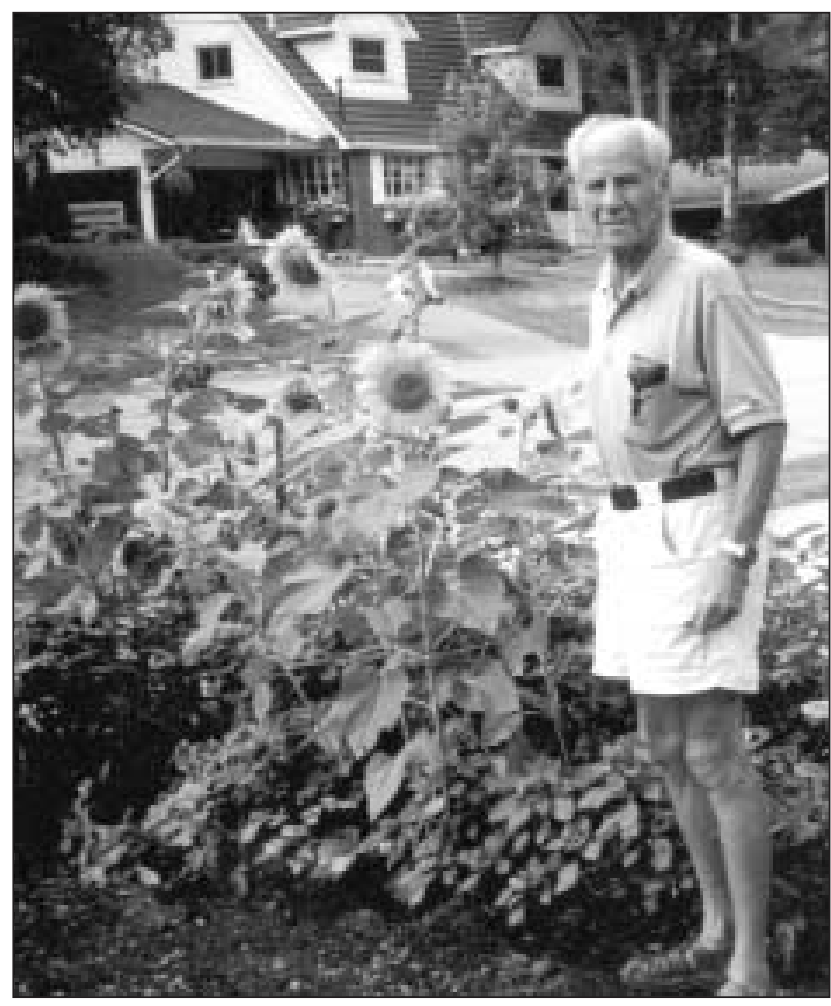

Fred von Althen worked as a research scientist for the Canadian Forest Service for over two decades. Now retired, Fred continues to lead an active life-skiing, gardening, and travelling widely. He is still consulted for his expertise on the establishment and growth of southern Ontario hardwoods.

(Acer_saccharinum L.), sycamore (Platanus occidentalis L.), white ash (Fraxinus americana L.), and white oak (Quercus alba L.). All species were southern Ontario seed sources. The layout was designed to test the effect of various planting arrangements (e.g., rows versus groups) on hardwood growth (see von Althen 1988 for details). Weed control consisted of herbicide applications in the spring of years 1 to 3 and 6 . Fertilization and thinning activities were not undertaken, but black walnut was pruned in 1985, and sycamore, white oak, red oak, white ash, basswood, and black walnut were pruned in 1988.

\section{Measurements}

Height and survival were measured in each of the first five years after planting (von Althen 1988). However, for the present work, records could only be obtained for years 3 and 5 . Height, diameter at breast height (DBH), and survival were measured in years 10,15 , and 20 ; records were available for each of these years. Growth records were not available for mountain ash, so only survival data is presented for this species.

In winter of 2004 (i.e., 30 years after planting), the plantation was re-measured as part of an investigation of investment opportunities for fast-growing plantations in Canada (NRCan 2005). The original experimental design, which importantly had very little effect on growth rates (von Althen 1988), was no longer discernible. Therefore, six circular plots were established by dividing the plantation into six quadrants and randomly locating a plot in each quadrant. This stratified random approach was used to ensure that we measured the 
full range of variation in growth at the site. The plots encompassed 228 trees and 0.21 ha-about $20 \%$ of the area of the plantation. Tree diameters were measured with a DBH tape and heights were taken with a digital hypsometer. Individual gross tree volumes were calculated using species-specific equations (Belanger 1973, Ferell and Lundgren 1976, Honer et al. 1983). Where species-specific equations were not available, a conical volume equation was employed (Titus and Morgan 1988).

\section{Results and Discussion \\ Species composition}

Due to degradation of the original experimental design, it was not possible to trace the survival of individual trees for the measurements in 2004. Thus, we present percent composition data to give a sense of how the composition of the plantation has changed over time. The values for age 30 are based on sample plots and thus involve a sampling error that is not present in previous years when mortality was assessed individually for all trees in the plantation.

Original stand density was $2222 \mathrm{stems} / \mathrm{ha}$ and was reduced to an average of 790 stems/ha at age 30 through natural mortality. Stand composition was divided relatively evenly between tree species at five years post-establishment, but varied considerably after 30 years (Table 1 ). Of particular note was the rapid decline in white and red oak. A report on the five-year survival and growth at this plantation (von Althen 1980) indicates that severe root pruning, which was done to facilitate mechanical planting, probably caused the low survival of oak seedlings. Sycamore also showed a relatively high rate of mortality. Given the northern location of the study area relative to sycamore's natural range, the early decline of this species (i.e., reduced to $6 \%$ of stand composition at year 5) may indicate a susceptibility of young plants to freeze damage. Conversely, European mountain ash and black locust had higher levels of mortality later in stand developmentbetween 20 and 30 years post-establishment. This is consistent with the generally accepted ecology of these species; both are considered early successional and relatively short-lived (Sullivan 1992, 1993).

Black walnut, white ash, silver maple, and basswood have increased their proportional presence in the stand due to relatively lower mortality rates. All of these species are well

Table 1. Proportional changes in species composition [\%] during the first $\mathbf{3 0}$ years of a mixed hardwood plantation.

\begin{tabular}{lccccc}
\hline & \multicolumn{5}{c}{ Plantation Age (years) } \\
\cline { 2 - 6 } Tree Species & 5 & 10 & 15 & 20 & 30 \\
\hline Basswood & 12 & 12 & 12 & 14 & 15 \\
Black locust & 11 & 13 & 14 & 12 & 7 \\
Black Walnut & 11 & 14 & 15 & 16 & 14 \\
Catalpa & 10 & 9 & 10 & 11 & 11 \\
Mountain Ash & 11 & 12 & 11 & 10 & 5 \\
Red Oak & 8 & 4 & 4 & 4 & 3 \\
Silver Maple & 11 & 13 & 12 & 10 & 19 \\
Sycamore & 6 & 6 & 5 & 5 & 3 \\
White Ash & 11 & 13 & 13 & 15 & 22 \\
White Oak & 9 & 4 & 4 & 3 & 1 \\
\hline
\end{tabular}

suited to growth at the latitude of the study area and are often found in mature mixed hardwood stands throughout the region. It should be noted that the relatively high survivorship shown by these species is dependent on considerable silvicultural input-particularly with respect to site preparation and competition control—early in plantation development (von Althen 1990). Left to natural successional pathways, many abandoned agricultural fields in this region are overtaken by shrubs (e.g., hawthorns - Crataegus spp.) and it may be decades before slow-growing, shade-tolerant species form a stand.

\section{Growth and yield}

There was considerable variation between species with respect to height growth (Table 2). Sycamore, white ash, and black walnut showed the highest height growth rates, while the two oak species had the lowest. With respect to $\mathrm{DBH}$, the fastest growing species were silver maple, catalpa, and white ash; again the oaks were the slowest growers (Table 3). In the case of both height and DBH, silver maple and black locust were the fastest growing species during the early stages of plantation development, but tailed off after about 20 years of age - a trait noted for both species in previous studies (Gabriel 1990, Huntley 1990). Highest yields were achieved by silver maple, white ash, and black walnut, with the oaks showing very poor production (Table 4 ).

The unique composition of this plantation makes comparison to other studies difficult. Nonetheless, there is evidence to suggest that the growth rates encountered here are high in comparison to other mixed hardwood stands. The Mean Annual Increment (MAI) of this plantation at 30 years is $6.1 \mathrm{~m}^{3} / \mathrm{ha} / \mathrm{yr}$. Love et al. (1972) studied the productivity of land in Ontario for growing hardwoods and reported MAI values from the most productive sites of $4.6 \mathrm{~m}^{3} / \mathrm{ha} / \mathrm{yr}$ and 5.6 $\mathrm{m}^{3} / \mathrm{ha} / \mathrm{yr}$ for shade-tolerant and shade-intolerant hardwood mixtures respectively. Stroempl (1983) quantified growth of a basswood-sugar maple stand in central Ontario. He reported an average total tree volume for basswood at age 30 of 0.11 $\mathrm{m}^{3}$ - compared to $0.22 \mathrm{~m}^{3}$ in the present study. Several studies have described the growth of northern hardwoods in the US and all reported yields about half of those presented here (Leak et al. 1969, Erdmann and Oberg 1973, Solomon and Leak 1986). We note that all the above comparisons involve

Table 2. Height growth $(\mathrm{m})$ during the first $\mathbf{3 0}$ years of a mixed hardwood plantation.

\begin{tabular}{lcccccc}
\hline & \multicolumn{7}{c}{ Plantation Age (years) } \\
\cline { 2 - 7 } Tree Species & 3 & 5 & 10 & 15 & 20 & 30 \\
\hline Basswood & 1.15 & 2.32 & 5.45 & 9.77 & 11.43 & 15.01 \\
Black Locust & 3.16 & 4.90 & 7.75 & 11.10 & 12.50 & 15.13 \\
Black Walnut & 0.92 & 2.26 & 5.60 & 9.37 & 11.67 & 16.25 \\
Catalpa & 1.36 & 2.77 & 5.22 & 9.00 & 10.90 & 14.83 \\
Red Oak & 0.53 & 0.74 & 4.01 & 5.50 & 12.15 & 9.05 \\
Silver Maple & 2.31 & 4.33 & 8.86 & 11.67 & 14.37 & 14.70 \\
Sycamore & 1.46 & 3.07 & 7.32 & 9.93 & 13.90 & 17.36 \\
White Ash & 0.91 & 2.06 & 5.70 & 9.83 & 13.20 & 16.63 \\
White Oak & 0.46 & 0.92 & 3.98 & 7.13 & 10.47 & 10.82 \\
\hline
\end{tabular}


Table 3. DBH growth (cm) during the first 30 years of a mixed hardwood plantation.

\begin{tabular}{lcccc}
\hline & \multicolumn{4}{c}{ Plantation Age (years) } \\
\cline { 2 - 5 } Tree Species & 10 & 15 & 20 & 30 \\
\hline Basswood & 6.93 & 10.90 & 14.47 & 20.12 \\
Black Locust & 10.80 & 14.70 & 15.87 & 16.99 \\
Black Walnut & 7.13 & 11.97 & 13.60 & 20.17 \\
Catalpa & 7.73 & 11.43 & 14.00 & 22.68 \\
Red Oak & 3.35 & 6.50 & 8.65 & 9.10 \\
Silver Maple & 12.50 & 17.67 & 21.27 & 22.36 \\
Sycamore & 8.13 & 11.47 & 15.13 & 18.28 \\
White Ash & 5.70 & 9.67 & 13.60 & 21.20 \\
White Oak & 2.97 & 6.23 & 9.23 & 10.62 \\
\hline
\end{tabular}

naturally regenerated forests where a lower rate of productivity might be expected due to increased competition early in stand development.

Mixed hardwood plantations appear to perform substantially better than hardwood monocultures in southern Ontario. Pedlar et al. (2006) summarized findings from 110 growth plots in hardwood plantations; after controlling for soil conditions, mixed hardwood plantations were found to grow at a rate about twice that of hardwood monocultures. There is a good ecological basis for the improved productivity that comes with mixed plantings. Kelty (1992) points out that mixed stands are often able to use site resources more efficiently due to differences between species in factors such as shade tolerance, leaf phenology, and root structure. Mixed plantations also reduce the risk of catastrophic losses resulting from insects, disease, and wind (von Althen 1988, Kelty 1992, Schmid and Kazda 2001). The current trend in southern Ontario toward multi-species plantings suggests that landowners and forest managers are beginning to recognize the improved productivity and reduced risk associated with the mixed species approach.

Northern catalpa, black locust, and sycamore exhibited good growth rates, though sycamore and locust did experience relatively high mortality. These results are noteworthy given that the study area is located at or beyond the northern edge of the published geographic range for these species. Based on predictions from general circulation models, a major reorganization of North American tree species is anticipated over the next 50 to 100 years; with the climate habitat of southern tree species potentially shifting hundreds of kilometres to the north (Shafer et al. 2001, Iverson et al. 2005). Landowners may soon have to consider future climate conditions when selecting tree species for planting activities. Data such as those presented here provide insight into which tree species may be appropriate for future planting efforts. Here again, the mixed species approach would allow landowners to hedge their bets against future climate change by planting species with a range of climatic tolerances.

\section{Conclusions}

The mixed hardwood plantation under study grew at a rate of $6.1 \mathrm{~m}^{3} / \mathrm{ha} / \mathrm{yr}$ at age 30 . This growth rate is higher than that
Table 4. Gross total yield $\left(\mathrm{m}^{3} / \mathrm{ha}\right)$ during the first 30 years of a mixed hardwood plantation.

\begin{tabular}{lcccc}
\hline & \multicolumn{4}{c}{ Plantation Age (years) } \\
\cline { 2 - 5 } Tree Species & 10 & 15 & 20 & 30 \\
\hline Basswood & 1.63 & 6.96 & 13.90 & 24.07 \\
Black Locust & 4.77 & 12.09 & 13.24 & 6.07 \\
Black Walnut & 2.09 & 9.68 & 14.75 & 29.67 \\
Catalpa & 0.96 & 3.81 & 6.21 & 18.89 \\
Red Oak & 0.12 & 0.59 & 1.36 & 0.35 \\
Silver Maple & 9.50 & 22.16 & 30.17 & 55.92 \\
Sycamore & 1.10 & 2.81 & 5.31 & 5.36 \\
White Ash & 0.91 & 4.44 & 11.41 & 39.28 \\
White Oak & 0.07 & 0.45 & 1.28 & 1.65 \\
\hline Total & 21.14 & 62.99 & 97.63 & 181.25 \\
\hline
\end{tabular}

reported for naturally occurring mixed stands in temperate North America. Fast-growing species included silver maple, black walnut, white ash, and basswood, but perhaps due to special circumstances, white and red oak grew surprisingly poorly. Both silver maple and black locust showed good growth at an early stage in plantation development, but declined after about 20 years.

As demand increases for mixed species plantations in southern Ontario, further research efforts are needed to better understand the effects that species composition, site characteristics and management techniques have on productivity and ecological sustainability. Given this plantation's unique composition and excellent growth rate, we feel that ongoing monitoring will provide insight into improved best practices in mixed species afforestation.

\section{Acknowledgements}

Funding for this project was provided by Natural Resources Canada - Canadian Forest Service, and the Forest 2020 Plantation Assessment and Demonstration program. The authors would like to thank Fred von Althen for his cooperation on all aspects of this research effort, and Garth Mitchell, Fred's research assistant, for his assistance in relocating the original study plots. Art Groot, Steve Dominy, and Darren Allen provided helpful suggestions for laying out the remeasurement plots, and Doug Pitt arranged for the use of a digital hypsometer. Thanks also to Kathy Campbell for mapping assistance and Kathy Hodgins for facilitating field work on Conservation Area land.

\section{References}

Belanger R. P. 1973. Volume and weight tables for plantation-grown sycamore. United States Department of Agriculture. Forest Service. Research Paper SE-107.

Erdmann G.G. and R.R. Oberg. 1973. Fifteen-year results from six cutting methods in second-growth northern hardwoods. United States Department of Agriculture. Forest Service. Research Paper NC-100.

Ferrell R. S. and A.L. Lundgren. 1976. Mathematical Functions for Predicting Growth and Yield of Black Walnut Plantations in the Central States. United States Department of Agriculture. Forest Service. General Technical Report NC-24. 
Gabriel W.J. 1990. Acer Saccharinum L. Silver Maple. In R.M. Burns and B.H. Honkala (tech. coords). 1990. Silvics of North America: 1. Conifers; 2. Hardwoods. Agriculture Handbook 654. U.S. Department of Agriculture, Forest Service, Washington, DC. vol.2. 877 p.

Honer T.G., M.F. Ker and I.S. Alemdag. 1983. Metric Timber Tables for the Commercial Tree Species of Central and Eastern Canada. Canadian Forest Service, Environment Canada. Information Report M-X-140.

Huntley J.C. 1990. Robinia pseudoacacia L. Black Locust. In R.M. Burns and B.H. Honkala (tech. coords.) 1990. Silvics of North America: 1. Conifers; 2. Hardwoods. Agriculture Handbook 654. U.S. Department of Agriculture, Forest Service, Washington, DC. vol.2. $877 \mathrm{p}$.

Iverson L.R., A.M. Prasad and M.W. Schwartz. 2005. Predicting potential changes in suitable habitat and distribution by 2100 for tree species of the eastern United States. J. Agric. Meteorol. 61:29-37. Kelty M.J. 1992. Comparative productivity of monocultures and mixed-species stands. In M.J. Kelty (ed.) The ecology and management of mixed species forests. pp. 125-141. Kluwer Academic Publisher, Dordrecht, Netherlands.

Leak W.B., D.S. Solomon and S.M. Filip. 1969. A silvicultural guide for northern hardwoods in the northeast. United States Department of Agriculture. Forest Service. Research Paper NE-143.

Love D.V., A.F. Beckwith and Z.J.R. Morawski. 1972. Studies of land productivity for hardwoods in southern Ontario. The Canada Land Inventory, ARDA Report No. 6.

Natural Resources Canada (NRCan). 2005. Forest 2020 Plantation Demonstration and Assessment. [online]. Available from http://www.nrcan-rncan.gc.ca/cfs-scf/national/what-quoi/afforestation/f2020_e.html [cited July 2006].

Pedlar, J.H., D.W. McKenney and S. Fraleigh. 2006. Planting black walnut in southern Ontario: midrotation assessment of growth, yield, and silvicultural treatments. Can. J. For. Res. 36: 495-504.

Schmid I. and M. Kazda. 2001. Vertical distribution and radial growth of coarse roots in pure and mixed stands of Fagus sylvatica and Picea abies. Can. J. For. Res. 31: 539-548.
Shafer S.L., P.J. Bartlein and R.S. Thompson. 2001. Potential changes in the distributions of western North America tree and shrub taxa under future climate scenarios. Ecosystems 4: 200-215.

Solomon D.S. and W.B. Leak. 1986. Simulated Yields for Managed Northern Hardwood Stands. United States Department of Agriculture. Forest Service. Research Paper NE-578.

Stroempl G. 1983. Growth response of basswood and sugar maple to an intermediate cutting. Ontario Ministry of Natural Resources. Forest Research Paper No. 107. 19 p.

Sullivan J. 1992. Sorbus americana. In Fire Effects Information System, U.S. Department of Agriculture, Forest Service, Rocky Mountain Research Station, Fire Sciences Laboratory. [online]. Available from http://www.fs.fed.us/database/feis/ [cited 28 December 2006].

Sullivan, J. 1993. Robinia pseudoacacia. In Fire Effects Information System, [Online].

U.S. Department of Agriculture, Forest Service, Rocky Mountain Research Station, Fire Sciences Laboratory. [online]. Available from http://www.fs.fed.us/database/feis/ [cited 28 December 2006].

Titus S.J. and D.J. Morgan. 1988. Theory and Methodology of Single Tree Volume Estimation. Canadian Forestry Service, Petawawa National Forestry Institute and Canadian Forest Inventory Committee. Information Report PI-X-85.

von Althen F.W. 1980. Five year survival and growth of sixteen hardwood species planted in different mixtures. Canadian Forest Service, Department of the Environment. Report 0-X-313.

von Althen F.W. 1988. Effects of spatial arrangement in mixedspecies hardwood plantations. Northern Journal of Applied Forestry 5: 203-207.

von Althen F.W. 1990. Hardwood planting on abandoned farmland in Southern Ontario. Minister of Supply and Services, Canada. 